\title{
Cavernoma of the lateral ventricule presenting as speech arrests
}

\author{
Leonardo Conrado Silva Lima', Marcelo Paglioli Ferreira², \\ Davidson Alba ${ }^{3}$, Alisson Roberto Teles ${ }^{4}$, Frederico Kliemann ${ }^{5}$
}

Division of Neurosurgery, Hospital São José, Irmandade da Santa Casa de Misericórdia, Porto Alegre, RS, Brazil.

\begin{abstract}
Cavernous malformations (CM) are formed by dilated thin-walled vascular channels without intervening parenchyma and intraventricular lesions are rare. We report a case of an intraventricular cavernoma in a 54-year old female patient. She presented with speech arrests daily for 10 months. Neurological examination revealed no deficits. The brain MRI study revealed an intraventricular lesion at the level of the left atrium, heterogeneously hyperintense on both $T 1$ and T2-weighted images. It was performed an interhemispheric transcallosal approach with gross-total resection of the lesion. The histological examination was compatible with the diagnosis of cavernous haemangioma. In the postoperative period the patient presented with transient right hemiparesis with recovery in two weeks. We briefly review the literature concerning intraventricular cavernomas.
\end{abstract}

\section{KEYWORDS}

Intracranial arteriovenous malformations, haemangioma cavernous, case reports.

\section{RESUMO}

Cavernoma do ventrículo lateral se apresentando como bloqueios da fala

Malformações cavenosas são formadas por canais vasculares dilatados e de paredes finas sem parênquima cerebral no interior. Lesões dessa natureza são raras nos ventrículos. Neste trabalho descrevemos um caso de cavernoma intraventricular em uma paciente feminina de 54 anos. Ela se apresentou clinicamente com bloqueios de fala diários nos últimos 10 meses. Nenhum déficit neurológico foi observado no exame. A ressonância magnética de encéfalo demonstrou lesão heterogênea na topografia do átrio ventricular esquerdo, hiperintensa em T1 e T2. Foi realizada abordagem interemisférica transcalosa com ressecção total da lesão. $A$ análise histopatológica foi compatível com hemangioma cavernoso. No período pós-operatório a paciente apresentou hemiparesia direita, que melhorou em duas semanas. Revisa-se brevemente a literatura em relação a cavernomas intraventriculares.

\section{PALAVRAS-CHAVE}

Malformações arteriovenosas intracranianas, hemangioma cavernoso, relatos de casos.

1 Neurosurgeon, Division of Neurosurgery, Hospital Portugues, Salvador, BA, Brazil.

2 Neurosurgeon, Division of Neurosurgery, Hospital São José, Irmandade da Santa Casa de Misericórdia, Porto Alegre, RS, Brazil.

3 Neurosurgeon, Division of Neurosurgery, Hospital de Caridade Dr. Astrogildo de Azevedo, Santa Maria, RS, Brazil.

4 Neurosurgery Resident, Division of Neurosurgery, Hospital São José, Irmandade da Santa Casa de Misericórdia, Porto Alegre, RS, Brazil.

5 Neurologist, Division of Neurology, Hospital São José, Irmandade da Santa Casa de Misericórdia, Porto Alegre, RS, Brazil. 


\section{Introduction}

Vascular malformations of the brain are classified into four major categories: arteriovenous malformations, cavernous malformations (CM), venous angiomas, and capillary telangiectasias. $\mathrm{CM}$ are formed by dilated thin-walled vascular channels without intervening parenchyma. They appear to grow by a process of vascular cavern proliferation in the setting of repetitive lesional hemorrhages. ${ }^{1}$

Intraventricular cavernomas are rare lesions. According to a recent review published by Kivelev et al., ${ }^{3}$ there are only 89 cases reported in literature. We described another case of a cavernoma of the lateral ventricle.

\section{Case report}

MACC, female 54-year old patient, nurse, has been suffering with speech arrests daily for 10 months. Episodes were preceded by an epigastric "bad feeling". On her past medical history, she was diagnosed with hypothyroidism (treated with levothyroxin) and with just one surgical previous treatment (cholecystectomy for cholelythiasis) years ago. The neurological exam revealed no abnormalities.

The brain MRI study revealed an intraventricular lesion at the level of the left atrium, heterogeneously hyperintense on both $\mathrm{T} 1$ and $\mathrm{T} 2$-weighted images (Figure 1A-E). The cerebral angiography showed no evidence of arterial or venous malformations. The electroencephalogram indicated epileptiform discharges on the left frontal and temporal areas, with no sphenoidal electrode abnormality seen.

The patient was submitted to an interhemispheric transcallosal approach with gross-total resection of the lesion. In the immediate postoperative period, the patient presented with right hemiparesis. The motor deficit improved during the following days, and within two weeks it was completely resolved. No episode of speech arrest was identified during hospitalization.

The histological examination of the lesion showed a grayish and brilliant tissue, with multiple dark layers and cavities filled with haematic material, compatible with the diagnosis of cavernous haemangioma.

One month after the surgery, the patient returned referring control of the crisis with medical treatment (phenytoin and lamotrigin). No new deficits were observed, and no other symptoms were related. One year after surgery the patient persisted with the same medical treatment and was seizure free.
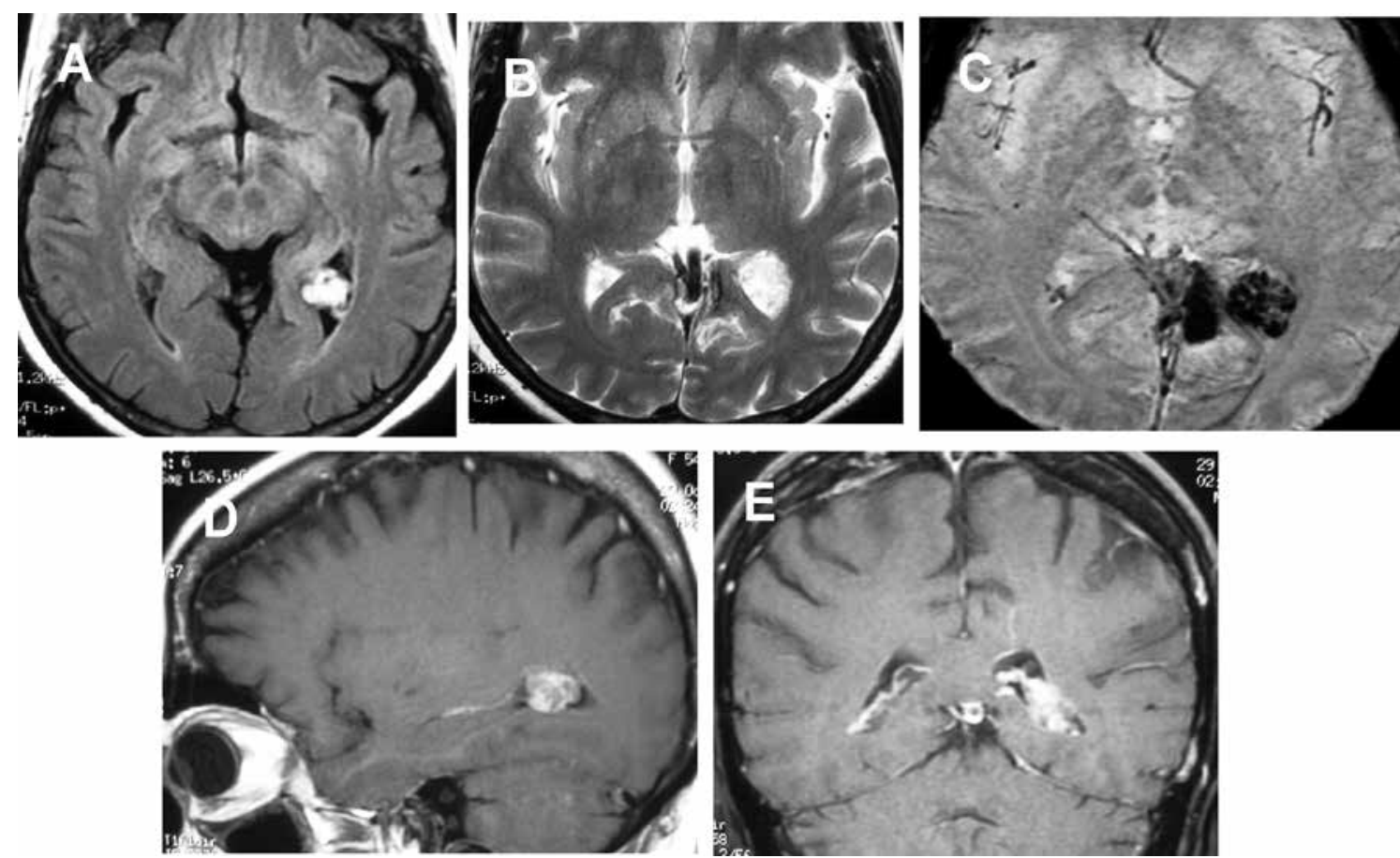

Figure 1 - Intraventricular cavernoma. MRI: axial T1-weighted with contrast (A), axial T2-weighted (B), echo-gradient (C), sagital (D) and coronal (E) T1-weighted. 


\section{Discussion}

The natural history of the intraventricular cavernomas has been widely discussed. It seems to be more common in females than in males. ${ }^{2,3}$ The annualized bleeding rates of central nervous system cavernomas are 0,25 to $0,7 \%$ per person/year. ${ }^{4,5}$ Kivelev et al. ${ }^{3}$ recently reviewed the literature regarding to intraventricular cavernomas and reported another 12 cases; 19 of 89 patients reported with intraventricular cavernomas presented with intraventricular hemorrhage.

In our case report, the patient presented with speech arrests during ten months. In previous studies, epileptic manifestations were identified in $14 \%$ and it was more common in lateral ventricle lesions. ${ }^{3}$ Cavernous malformations are not intrinsically epileptogenic, but they can induce seizures through their effect on the surrounding brain tissue. These effects may include ischemia, venous hypertension, gliosis, deposits of blood breakdown products, and cellular and humoral inflammatory responses. Lesions may induce changes in brain tissue located at a significant distance from the primary epileptogenic focus, and this may contribute to an epilepsy syndrome, and even to independent distant foci of epileptogenicity. ${ }^{1}$

Iwasa et al. ${ }^{6}$ and Voigt and Yasargil ${ }^{7}$ stated that the most frequent initial symptoms are seizures, headache and subarachnoid hemorrhage. Hydrocephalus is a common presentation in patients with third and fourth ventricle lesions. $^{2,3}$

CT findings associated with cavernomas consist of a well-circumscribed high-density area, absence of perifocal edema, and mild or no contrast enhancement. The characteristic appearance of cavernomas on MR images is a central area of hypersignal correlated to the presence of methemoglobin, associated with areas of hyposignal caused by calcifications and fibrosis within the lesion on T1- and T2-weighted images. A peripheral rim of hyposignal caused by hemosiderin paramagnetic effect is often present. ${ }^{8}$ The gradient echo sequence is very helpful. ${ }^{1,9}$ Cavernomas are angiographically occult malformations because their connections with the vascular system are generally poor., ${ }^{8,10}$ The electroencephalography usually shows nonspecific abnormalities and is not helpful in localizing the lesion. ${ }^{2}$

Surgical treatment is indicated in patients with intractable seizures, in those with previous hemorrhage and when the mass effect cause progressive neurological deterioration. ${ }^{3,5}$ The removal of the cavernous angiomas may reduce the frequency and severity of seizures, and may result in complete cure of seizure disorder. ${ }^{4}$ Lesionrelated epilepsy is postulated to be permanent or to be independent of the instigating pathology after a longer duration of epileptogenicity. ${ }^{1}$
A favorable outcome can be expected after the surgical removal of intraventricular cavernomas, ${ }^{2}$ but the location of lesion is relevant. ${ }^{7}$ Surgery in the lateral ventricle has less morbidity when comparable to third and fourth ventricles. One of the most common approaches to this location is the interhemispherictranscallosal. Postoperative hemiparesis is a common reversible complication and must be associated with use of brain retraction. ${ }^{11}$

\section{References}

1. Awad I, Jabbour P. Cerebral cavernous malformations and epilepsy. Neurosurg Focus. 2006;21(1):e7.

2. Chadduck WM, Binet EF, Farrell FW Jr, Araoz CA, Reding DL. Intraventricular cavernous hemangioma: report of three cases and review of the literature. Neurosurgery. 1985;16(2):189-97.

3. Kivelev J, Niemelä M, Kivisaari R, Hernesniemi J. Intraventricular cerebral cavernomas: a series of 12 patients and review of the literature. J Neurosurg. 2010;112(1):140-9.

4. Del Curling O Jr, Kelly DL Jr, Elster AD, Craven TE. An analysis of the natural history of cavernous angiomas. $J$ Neurosurg. 1991;75(5):702-8.

5. Robinson JR, Awad IA, Little JR. Natural history of the cavernous angioma. J Neurosurg. 1991;75(5):709-14.

6. Iwasa $\mathrm{H}$, Indei I, Sato F. Intraventricular cavernous hemangioma. Case report. J Neurosurg. 1983;59(1):153-7.

7. Voigt K, Yasargil MG. Cerebral cavernous haemangiomas or cavernomas. Incidence, pathology, localization, diagnosis, clinical features and treatment. Review of the literature and report of an unusual case. Neurochirurgia (Stuttg). 1976;19(2):59-68.

8. Reyns N, Assaker R, Louis E, Lejeune JP. Intraventricular cavernomas: three cases and review of the literature. Neurosurgery. 1999;44(3):648-54.

9. Anderson RC, Connolly ES Jr, Ozduman K, Laurans MS, Gunel M, Khandji A, et al. Clinicopathological review: giant intraventricular cavernous malformation. Neurosurgery. 2003;53(2):374-8.

10. Pozzati E, Gaist G, Poppi M, Morrone B, Padovani R. Microsurgical removal of paraventricular cavernous angiomas. Report of two cases. J Neurosurg. 1981;55(2):308-11.

11. Fagundes-Pereyra WJ, Marques JA, Sousa LD, Carvalho GT, Sousa AA. Cavernoma of the lateral ventricle: case report. Arq Neuropsiquiatr. 2000;58(3B):958-64.

\footnotetext{
Correspondence address

Leonardo Conrado Silva Lima

Rua da Graviola, 264, Caminho das Árvores

41820-360 - Salvador, BA, Brazil

Telephone: (71) 9168-2996

E-mail: leo_conrado@hotmail.com
} 